Dept. of Animal and Poultry Production,

Fac. of Agriculture, Assiut University.

\title{
PERFORMANCE OF FATTENING BUFFALO CALVES FED DIFFERENT LEVELS OF DRIED POULTRY MANURE
}

(With 8 Tables)

\section{By}

\author{
M.N.M. ABD EL-ATI and A.N. SAYED*
}

* Dept. of Animal and Clinical Nutrition, Fac. of Vet. Med., Assiut University

(Received at 3/9/2008)

أداء عجول الجاموس المغذاة علي مستويات مختلفة من زرق الدواجن الجاف

\section{محد نصرث عبدالعاطي ، عبل الباسط نصر سبا}

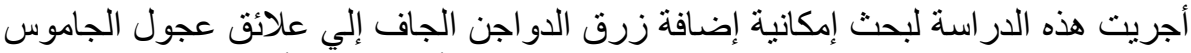

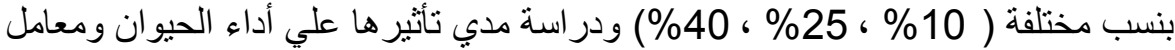
هضم المو اد الغذائية بالإضافة إلي صفات الكرش و

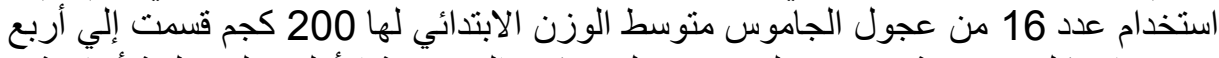

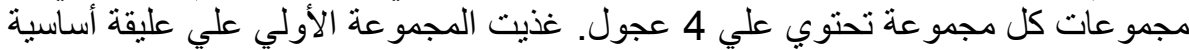

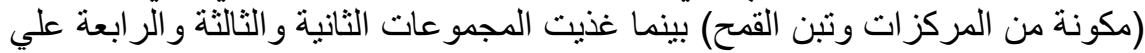

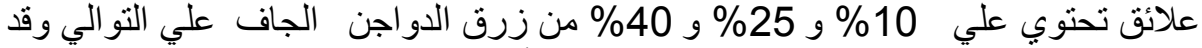

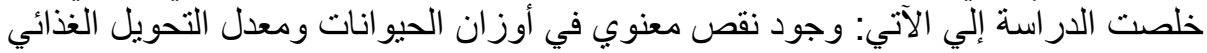

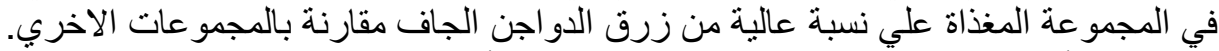

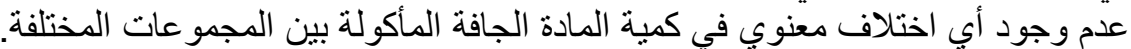

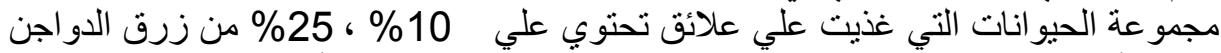

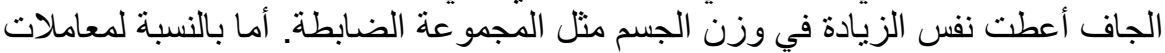

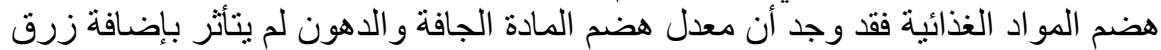

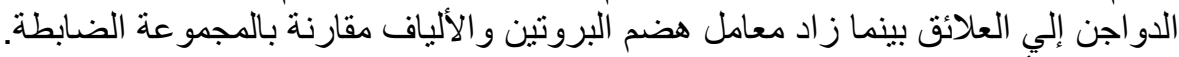

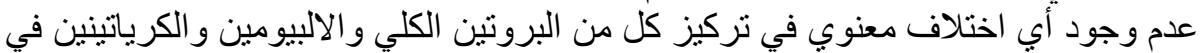

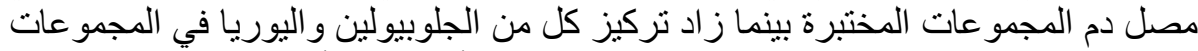

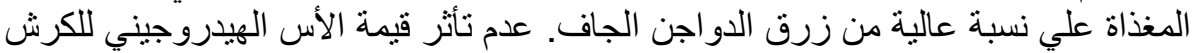

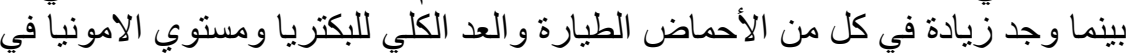

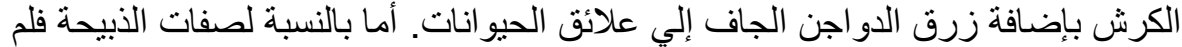

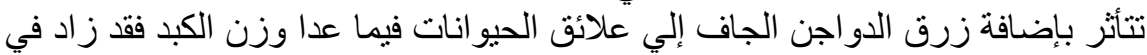

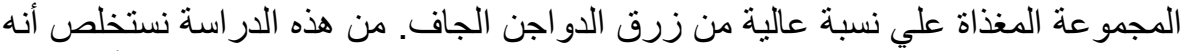

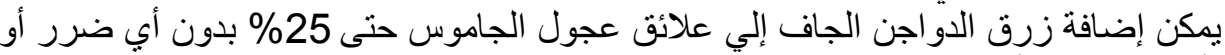
تأثثر سئ علي أداء الحيو انات و عامل هضم المو اد الغذائية وبالتالي يمكن التغلب علي مشكلة التي 


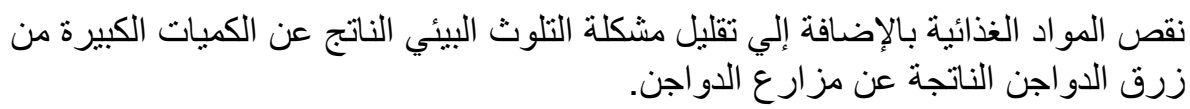

\section{SUMMARY}

Feeding of farm animals encounters many problems in Egypt as well as in many countries of similar conditions due to the limited availability of resources. The main objective of the experiment was to study the effect of incorporating dried cage poultry manure (DPM) at different levels $(0,10,25$ and $40 \%)$ into isonitrogenous rations fed to fattening buffalo calves (for 90 days) on the performance \& digestibility of nutrients. Rumen liquor characteristics $\left(\mathrm{pH}, \mathrm{NH}_{3}-\mathrm{N}\right.$, total volatile fatty acids and bacterial counts) and blood parameters (total protein, albumin, globulin, urea \& creatinine) were also studied. Sixteen buffalo calves of average initial body weight $200 \mathrm{Kg}$ were divided randomly into four groups (4 calves in each). The first group (control) was fed on the basal ration. The second, third and fourth groups were fed on rations in which dried poultry manure replaced $10,25 \& 40 \%$ of the basal ration, respectively. Results indicated that the inclusion of high levels of dried poultry manure $(40 \%)$ had significantly $(\mathrm{P}<0.05)$ decreased average daily gain $\&$ feed conversion compared to the other experimental groups. No significant differences in dry matter intake between different experimental groups were noticed. Calves fed on the $10 \& 25 \%$ DPM had nearly the same average daily gain as the control one. Dry matter and ether extract digestibility coefficients were not affected by DPM incorporation. Digestibility coefficients of crude protein and crude fibre were higher in rations containing DPM compared to control one. Blood serum total protein, albumin and creatinine were not affected significantly, while there were significant increase $(\mathrm{P}<0.05)$ in globulin and urea values in the group fed ration containing the higher level of DPM. Ruminal $\mathrm{pH}$ was not affected by DPM addition, while there was significant differences $(\mathrm{P}<0.05)$ in the total volatile fatty acids \& total bacterial counts between the experimental groups. Rumen $\mathrm{NH}_{3}-\mathrm{N}$ was increased significantly $(\mathrm{P}<0.05)$ by increasing DPM levels in the rations of calves. It seems that carcass traits were not affected by the incorporation of DPM in the ration of fattening buffalo calve except slight increase in liver weight of the high level (DPM) groups. In general, it may be concluded that dried poultry manure can be utilized efficiently and safely in rations for fattening buffalo calves up to the level of $25 \%$ without serious adverse effects on performance, 
digestibility, rumen and blood parameter and carcass traits. This result could be a useful mean to overcome feed shortage and minimize feed costs. Moreover, using DPM in animal feeds will alleviate pollution problems and considered a factor in the biosecurity of the animal production.

Key Words: Evaluation, poultry manure, fattening, buffalo, calves

\section{INTRODUCTION}

The commercial poultry industry produces significant amounts of poultry wastes. Disposal of poultry waste is the major problem for large scale \& intensive poultry operations. Refeeding poultry wastes, particularly to ruminants may be a feasible solution of alleviating the poultry wastes disposal problem as well as a method for recovering some of the potentially valuable nutrients that it contains (Abd El-Ghani et al., 1999). Feeding of farm animals encounters many problems in many countries due to the limited availability of resources. In Egypt, against background of a rapidly increasing population that demands protein, there is additional need to decrease cost of feed. It has been suggested that farmers make use of non conventional feeds in their animal's diets to reduce the need for purchasing of marketable feeds (Abd El-Ghani et al., 1999). Numerous scientific studies showed that the utilization of poultry wastes (litter and manure) as a source of protein is considered to be the most strategic ingredients of the unconventional feeding system of ruminants (El-Ashry et al., 1987 \& 2000; Gabr et al., 1991, 1993 \& 2001). Many published reports indicated that poultry wastes could be used in ruminant rations owing to low cost ingredients and decreasing the cost of meat production (Gihad et al., 1980). When processed by an acceptable method, poultry manure is an economical and safe source of protein, minerals and energy for many classes of ruminants (Kunkle et al., 1997). Poultry waste is valuable mainly for its nitrogen content and fibre and several reports indicated that crude protein content ranged from 25.3 to $34.7 \%$ (Harmon et al., 1975 \& Caswell et al., 1978). However, little attention has been focused on the effects of feeding rations containing dried poultry droppings on productive performance and meat quality of fattening buffalo calves and more knowledge and information are needed in this respect. Therefore, the main objective of the present work was to study the effect of replacing concentrate feed mixture with dried poultry manure at different levels on productive performance and carcass traits of fattening buffalo 
calves. Nutrient digestibilities, some rumen parameters and blood constituents as affected by dietary treatments were also studied.

\section{MATERIALS and METHODS}

\section{1-Animals \& feeding:}

Sixteen buffalo calves averaging $200 \mathrm{~kg}$ were used in the experiment. The animals were clinically healthy and the parasitological examination revealed no gastrointestinal infestation. The calves were divided randomly into four groups (4 calves in each). The first group was fed on the basal ration and considered as control. The second, third and fourth groups were fed on rations in which dried poultry manure replaced $10,25 \& 40 \%$ of the basal ration. All the experimental rations were chemically analyzed and formulated to provide the recommended levels of crude protein (12.3\%) and metabolizable energy $(2.7 \mathrm{Mcal} / \mathrm{kg}$ diet) according to the NRC (1984) as shown in Tables (1 and 2). The rations were composed of concentrate mixture and grinded wheat straw as roughage. The animals were offered each's quota of mixed ration. The rations were given twice daily and any residues were collected and weighed through the whole experiment (90 days) and all animals had free access to clean water. For estimating digestibility, chromic oxide was mixed with the ingredients at a rate of $0.5 \%$ as an indicator. At the end of the experimental period, calves were slaughtered for carcass traits evaluation.

\section{2-Samples:}

\section{1-Feeds \& fecal matter:}

Feed ingredients used in the experimental rations were sampled, dried, ground and analyzed for different nutrients. Representative samples of fecal matter were taken over 6 days at the end of the experiment, then dried for 24 hours at $60^{\circ} \mathrm{C}$, pooled together, mixed ground and stored till analysis.

\section{2-Blood:}

Blood samples were taken before the morning meal from the jugular vein in a dry, clean \& sterile centrifuge tubes. The samples were allowed to be clotted at room temperature. The clotted blood samples were centrifuged at $3000 \mathrm{rpm}$ for 20 minutes. A clear, non haemolyzed sera were separated by Pasteur-pipette and transferred into clean, dry and sterile stoppered glass vials till performing biochemical analysis.

\section{3-Analysis:}


Feed ingredients, rations and fecal samples were analyzed according to AOAC (1990).

\section{4-Digestibility determination:}

From the analysis of feed, fecal matter \& tracing the concentration of chromic oxide (Williams et al., 1962), digestibility was calculated.

\section{5-Biochemical parameters:}

Total serum protein, albumin, urea and creatinine were determined using standard kits supplied by Bio-Merieux (Baines/France).

\section{6-Statistical analysis:}

Statistical analysis of the collected data were carried out according to procedures of completely random design, SAS (1995).

\section{RESULTS and DISCUSSION}

Dry matter intake, average daily gain and feed conversion of the different experimental groups are shown in Table (3). No significant differences in the dry matter intake were observed between the experimental groups. This indicates that the palatability of the tested rations was not affected by the incorporation of dried poultry manure. This was agreed with that reported in the previous investigations with other animals (Kishan et al., 1984; Lal et al., 1986; Abdel-Gawad et al., 1989 \& Okeudo \& Adegbola, 1993) who reported that incorporating dried poultry manure did not significantly affect dry matter intake. Calves fed the ration containing high level of DPM (40\%) had decreased significantly $(\mathrm{P}<0.05)$ average daily gain $(867.67 \mathrm{~g} / \mathrm{d})$ compared to the control (1000 g/d) and groups fed on $10 \& 25 \%$ DPM $(933.3 \& 988.89$ $\mathrm{g} / \mathrm{d}$, respectively). However, reduced calve performance recorded with high level of DPM may be attributed to energy dilution (Kishan et al., 1984). Similar results were obtained in the previous studies with cattle, buffaloes \& sheep (Hadjipanayiotou et al., 1993; McCaskey et al., 1994 \& Helali et al., 1995). At higher levels of poultry manure, growth rate was depressed as well, probably because dried poultry manure is low in the essential amino acids needed by the animal and because of excessive amount of calcium as reported by Okeudo \& Adegbola (1993) and Bhattacharya (1996).

Results concerning the digestion coefficients of the nutrients are shown in Table (4). Digestibility coefficients of crude protein and crude fibre were significantly $(\mathrm{P}<0.05)$ higher in ration containing DPM. The improvement in $\mathrm{CP}$ digestibility could be either due to increase 
microbial protein synthesis in the rumen caused by more degradable protein in the form of NH3-nitrogen being available to rumen microbes (Mehrez, 1992) and/or to the complementary effect of undegradable ration protein and microbial protein (Orskov, 1982). The improve in CF digestibility may came in agreement with El-Ashry et al. (1987) who stated that the inclusion of wastes may be associated with increased NPN intake which may have improve CF digestibility.

No significant differences were observed among different treatments in total protein, albumin and creatinine in the blood serum (Table, 5). These results are similar to those obtained by Cross et al. (1978) and Khattab et al. (1982 \& 1995). Globulin concentration indicated that the experimental animals developed a kind of immunological status to infection with increasing levels of DPM, since globulin values expressed the immunity status of the animal (Kitchennham et al., 1975). Urea concentration was significantly $(\mathrm{P}<0.05)$ higher in the serum of calves fed on high DPM levels. This may be due to the high non protein nitrogen of the DPM. These results are in accordance with those reported by Mabjeesh et al. (1996).

The obtained results revealed that DPM levels did not significantly affect ruminal $\mathrm{pH}$ values (Table, 6). Similar results reported by Yildiz et al. (1995) and Gabr et al. (2003). There was significant $(\mathrm{P}<0.05)$ differences in the total bacterial count and total volatile fatty acids (TVFAs) and the high level of DPM (40\%) recorded the lowest value. These results agreed with that reported by Mudgal et al. (1983) who found gradual decrease in the rumen microbes with the increase of DPM level in the ration. The same was recorded by Chen \& Jan (1992) and Gabr et al. (2001) who found that TVFAs concentrations were slightly decreased with increased level of DPM. Rumen NH3-N was increased significantly $(\mathrm{P}<0.05)$ with increasing DPM level in the ration and this may be attributed to the relatively high nitrogen content of the DPM (Bhattacharya \& Taylor, 1975).

Results of the carcass traits (Table, 7) concluded that DPM exerted no significant effects on carcass traits except slight increase in the weight of liver at high level of DPM. This agreed with that reported by Ilian et al. (1988); Khattab et al. (1995) and Gabr et al. (2003). However, no signs of toxicity or impaired performance were observed in the experimental animal tissues.

Table (8) show feed costs of live body gain and economic feed efficiency. Feed cost of the ration containing DPM was significantly $(\mathrm{P}<0.05)$ lower than that of control one. Results obtained in the present 
study concluded that the use of rations containing $10 \%, 25 \%$ \& $40 \%$ poultry litter for calves increased economic feed efficiency to $130.67 \%$, $164.07 \& 190.07 \%$, respectively compared to control ration.

In general, it may be concluded that dried poultry manure can be utilized efficiently and safely in rations for fattening buffalo calves up to the level of $25 \%$ without serious adverse effects on performance, digestibility, rumen and blood parameter and carcass traits. This result could be a useful mean to overcome feed shortage and minimize feed costs. Moreover, using DPM in animal feeds will alleviate pollution problems and considered a factor in the biosecurity of the animal production.

Table 1: Chemical composition (\%) of the feed ingredients used in diets.

\begin{tabular}{|l|c|c|c|c|c|c|c|c|c|}
\hline \multirow{2}{*}{ Ingredients } & \multirow{2}{*}{$\mathrm{DM}$} & \multicolumn{9}{|c|}{ CP } & EE & CF & Ash & NFE & $\begin{array}{c}\text { ME } \\
\text { Mcal / kg DM }\end{array}$ & Ca & $\mathrm{p}$ \\
\cline { 3 - 10 } & & & & & & & 3.11 & 0.03 & 0.27 \\
\hline Corn, ground & 89.0 & 9.4 & 4.2 & 2.8 & 1.8 & 81.8 & 3.15 & 0.35 & 0.68 \\
SBOM & 89.6 & 45.1 & 1.4 & 7.6 & 6.3 & 39.6 & 2.67 & 0.16 & 1.36 \\
Wheat bran & 90.0 & 16.8 & 4.8 & 12.6 & 6.8 & 59.0 & 1.0 & 0.16 & 0.04 \\
Wheat straw & 93.0 & 3.4 & 0.5 & 35.2 & 18.0 & 42.9 & 1.60 & 2.30 & 1.60 \\
Poultry litter & 84.5 & 25.3 & 2.3 & 18.6 & 14.1 & 39.7 & 1.93 & - & - \\
Molasses & 73.7 & 4.3 & 0.4 & - & 10.0 & 85.3 & 2.76 & - & \\
\hline
\end{tabular}

Table 2: Physical \& chemical composition of the experimental rations $(\%)$

\begin{tabular}{|l|c|c|c|c|}
\hline \multirow{2}{*}{ Ingredients } & \multicolumn{4}{c|}{ Experimental rations } \\
\cline { 2 - 5 } & $\begin{array}{c}1 \\
\text { Control }\end{array}$ & $\begin{array}{c}2 \\
(10 \% \mathrm{DPM})\end{array}$ & $\begin{array}{c}3 \\
(25 \% \mathrm{DPM})\end{array}$ & $\begin{array}{c}4 \\
\text { (40\% DPM) }\end{array}$ \\
\hline I-Physical composition (\%): & & & & \\
Corn, ground & 41.33 & 36.19 & 29.20 & 18.1 \\
Soybean meal & 13.05 & 9.64 & 4.90 & 0.00 \\
Dried poultry manure & 00.00 & 10.00 & 25.00 & 40.00 \\
Wheat bran & 9.00 & 6.00 & 0.00 & 0.00 \\
Dried fat & 3.80 & 5.90 & 9.00 & 10.00 \\
Limestone, ground & 0.92 & 0.37 & 0.00 & 0.00 \\
Common salt & 1.00 & 1.00 & 1.00 & 1.00 \\
Mineral mixture & 0.15 & 0.15 & 0.15 & 0.15 \\
Vitamin mixture & 0.25 & 0.25 & 0.25 & 0.25 \\
Chromic oxide & 0.50 & 0.50 & 0.50 & 0.50 \\
Wheat straw & 30.00 & 30.00 & 30.00 & 30.00 \\
II-Chemical composition (\%): & & & & \\
Crude protein & 12.31 & 12.31 & 12.30 & 12.84 \\
Calcium & 0.47 & 0.47 & 0.66 & 0.98 \\
Phosphorus & 0.33 & 0.42 & 0.52 & 0.70 \\
ME (Mcal/Kg DM) & 2.71 & 2.71 & 2.70 & 2.57 \\
\hline
\end{tabular}

Table 3: Performance and feed efficiency of fattening buffalo calves 
Assiut Vet. Med. J. Vol. 54 No. 119 October 2008

\begin{tabular}{|l|c|c|c|c|}
\hline \multirow{2}{*}{ Items } & \multicolumn{4}{|c|}{ Experimental groups } \\
\cline { 2 - 5 } & $\begin{array}{c}1 \\
\text { Control }\end{array}$ & $\begin{array}{c}2 \\
(10 \% \mathrm{DPM})\end{array}$ & $\begin{array}{c}3 \\
(25 \% \mathrm{DPM})\end{array}$ & $\begin{array}{c}4 \\
(40 \% \mathrm{DPM})\end{array}$ \\
\hline Initial body weight $(\mathrm{kg})$ & 200 & 201 & 199 & 202 \\
Final body weight $(\mathrm{kg}):$ & & & & \\
$\quad 1^{\text {st }}$ month & 248 & 233 & 228 & 234 \\
$2^{\text {nd }}$ month & 268 & 262 & 257 & 253 \\
$3^{\text {rd }}$ month & $290 \pm 6.15^{\mathrm{a} *}$ & $285 \pm 8.31^{\mathrm{a}}$ & $288 \pm 5.60^{\mathrm{a}}$ & $280 \pm 7.13^{\mathrm{b}}$ \\
Total weight gain $(\mathrm{kg})$ & 90 & 84 & 89 & 78 \\
Average daily gain $(\mathrm{g})$ & $1000.0 \pm 5.72^{\mathrm{a}}$ & $933.3 \pm 7.16^{\mathrm{a}}$ & $988.89 \pm 8.30^{\mathrm{a}}$ & $867.67 \pm 9.11^{\mathrm{b}}$ \\
Growth rate $(\%)$ & 45 & 41.97 & 44.72 & 38.61 \\
Total dry matter intake $(\mathrm{kg} / \mathrm{h} / \mathrm{d})$ & 8.80 & 9.10 & 8.98 & 8.70 \\
Feed conversion ratio & 9.90 & 9.75 & 9.08 & 10.03 \\
\hline
\end{tabular}

*Figures in the same row having the different superscripts are significantly different $(\mathrm{P}<0.05)$

Table 4: Digestion coefficients of nutrients \& nutritive value of the experimental rations.

\begin{tabular}{|l|l|l|l|l|}
\hline \multirow{2}{*}{ Items } & \multicolumn{4}{|c|}{ Experimental groups } \\
\cline { 2 - 5 } & \multicolumn{1}{c|}{$\begin{array}{c}1 \\
\text { Control }\end{array}$} & $\begin{array}{c}\text { 2 } \\
(10 \% \mathrm{DPM})\end{array}$ & $\begin{array}{c}3 \\
(25 \% \mathrm{DPM})\end{array}$ & $\begin{array}{c}4 \\
(40 \% \mathrm{DPM})\end{array}$ \\
\hline Dry matter (\%) & $70.15 \pm 0.28$ & $71.02 \pm 2.21$ & $69.33 \pm 1.26$ & $68.10 \pm 0.88$ \\
Crude protein (\%) & $62.32 \pm 1.97^{\mathrm{b}}$ & $63.20 \pm 1.10^{\mathrm{b}}$ & $70.10 \pm 1.39^{\mathrm{a}}$ & $70.81 \pm 1.20^{\mathrm{a}}$ \\
Ether extract (\%) & $67.13 \pm 0.79$ & $66.73 \pm 0.74$ & $65.12 \pm 0.93$ & $65.30 \pm 0.67$ \\
Crude fibre (\%) & $57.51 \pm 1.20^{\mathrm{b}}$ & $59.12 \pm 1.01^{\mathrm{b}}$ & $64.33 \pm 1.50^{\mathrm{a}}$ & $62.43 \pm 1.03^{\mathrm{a}}$ \\
Nitrogen-free extract & $71.20 \pm 0.33$ & $70.35 \pm 0.28$ & $69.71 \pm 0.26$ & $70.32 \pm 0.50$ \\
\hline
\end{tabular}

* Figures in the same row having the different superscripts are significantly different $(\mathrm{P}<0.05)$

Table 5: Serum biochemical parameters of experimental groups

\begin{tabular}{|l|l|l|l|l|}
\hline \multirow{2}{*}{ Items } & \multicolumn{4}{|c|}{ Experimental groups } \\
\cline { 2 - 5 } & \multicolumn{1}{|c|}{$\begin{array}{c}1 \\
\text { Control }\end{array}$} & $\begin{array}{c}\text { 2 } \\
(10 \% \mathrm{DPM})\end{array}$ & $\begin{array}{c}3 \\
(25 \% \mathrm{DPM})\end{array}$ & $\begin{array}{c}4 \\
(40 \% \mathrm{DPM})\end{array}$ \\
\hline Total protein (g/dl) & $8.56 \pm 0.06$ & $8.70 \pm 0.04$ & $8.30 \pm 0.02$ & $8.82 \pm 0.05$ \\
Albumin $(\mathrm{g} / \mathrm{dl})$ & $4.75 \pm 0.01$ & $4.82 \pm 0.03$ & $4.30 \pm 0.05$ & $4.51 \pm 0.01$ \\
Globulin $(\mathrm{g} / \mathrm{dl})$ & $3.81 \pm 0.05^{\mathrm{b}}$ & $3.88 \pm 0.01^{\mathrm{b}}$ & $4.00 \pm 0.02^{\mathrm{a}}$ & $4.31 \pm 0.04^{\mathrm{a}}$ \\
Urea-N (mg/dl) & $30.66 \pm 0.50^{\mathrm{b}}$ & $31.50 \pm 0.56^{\mathrm{b}}$ & $35.79 \pm 0.40^{\mathrm{a}}$ & $36.47 \pm 0.37^{\mathrm{a}}$ \\
Creatinine (mg/dl) & $1.23 \pm 0.01$ & $1.32 \pm 0.02$ & $1.35 \pm 0.01$ & $1.39 \pm 0.04$ \\
\hline
\end{tabular}

*Figures in the same row having the different superscripts are significantly different $(\mathrm{P}<0.05)$

Table 6: Rumen liquor characteristics of experimental groups. 


\begin{tabular}{|l|l|c|l|l|}
\hline \multirow{2}{*}{ Items } & \multicolumn{4}{|c|}{ Experimental groups } \\
\cline { 2 - 5 } & \multicolumn{1}{|c|}{$\begin{array}{c}1 \\
\text { Control }\end{array}$} & $\begin{array}{c}2 \\
(10 \% \mathrm{DPM})\end{array}$ & $\begin{array}{c}3 \\
(25 \% \mathrm{DPM})\end{array}$ & $\begin{array}{c}4 \\
(40 \% \mathrm{DPM})\end{array}$ \\
\hline pH of the rumen & $5.98 \pm 0.04$ & $5.94 \pm 0.20$ & $5.88 \pm 0.10$ & $6.01 \pm 0.15$ \\
VFA conc. (meq/100ml R.L & $12.57 \pm 0.25^{\mathrm{a}}$ & $12.67 \pm 0.20^{\mathrm{a}}$ & $12.49 \pm 0.46^{\mathrm{a}}$ & $10.01 \pm 0.50^{\mathrm{b}}$ \\
Ammonia (meq/100 ml R.L) & $21.22 \pm 0.62^{\mathrm{b}}$ & $23.15 \pm 0.55^{\mathrm{b}}$ & $27.32 \pm 0.68^{\mathrm{a}}$ & $29.40 \pm 0.47^{\mathrm{a}}$ \\
Total bacterial count ( / ml) & $10.38 \times 10^{9} \mathrm{a}$ & $12.1 \times 10^{8 \mathrm{a}}$ & $13.2 \times 10^{7 \mathrm{~b}}$ & $8.32 \times 10^{7} \mathrm{~b}$ \\
\hline
\end{tabular}

*Figures in the same row having the different superscripts are significantly different $(\mathrm{P}<0.05)$

Table 7: Carcass traits of the experimental groups.

\begin{tabular}{|l|c|c|c|c|}
\hline \multicolumn{1}{|c|}{ Items } & \multicolumn{4}{c|}{ Experimental groups } \\
\cline { 2 - 5 } & $\begin{array}{c}1 \\
\text { Control }\end{array}$ & $\begin{array}{c}2 \\
(10 \% \text { DPM })\end{array}$ & $\begin{array}{c}3 \\
(25 \% \text { DPM })\end{array}$ & $\begin{array}{c}4 \\
(40 \% \mathrm{DPM})\end{array}$ \\
\hline Fasting body weight $(\mathrm{kg})$ & 281.7 & 275.1 & 269.7 & 255.5 \\
Empty body weight (kg) & 246.1 & 239.5 & 225.2 & 220.3 \\
Hot carcass weight (kg) & 143.0 & 137.0 & 133.0 & 132.0 \\
Dressing \% based on fasting wt & 50.76 & 49.8 & 49.31 & 51.66 \\
Dressing \% based on empty wt & 58.1 & 57.2 & 59.06 & 59.92 \\
Head weight (kg) & 16.51 & 15.72 & 14.83 & 14.10 \\
Heart (kg) & 1.05 & 1.05 & 1.07 & 1.07 \\
Liver (kg) & $2.80^{\mathrm{b}}$ & $3.01^{\mathrm{a}}$ & $3.25^{\mathrm{a}}$ & $3.36^{\mathrm{a}}$ \\
Kidney (kg) & 0.65 & 0.60 & 0.59 & 0.66 \\
\hline
\end{tabular}

*Figures in the same row having the different superscripts are significantly different $(\mathrm{P}<0.05)$

Table 8: Economic evaluation of calves body weight gain in the different experimental groups.

\begin{tabular}{|l|c|c|c|c|}
\hline \multirow{2}{*}{} & \multicolumn{4}{c|}{ Experimental groups } \\
\cline { 2 - 5 } & $\begin{array}{c}1 \\
\text { Control }\end{array}$ & $\begin{array}{c}2 \\
(10 \% \text { DPM })\end{array}$ & $\begin{array}{c}3 \\
(25 \% \text { DPM })\end{array}$ & $\begin{array}{c}4 \\
(40 \% \text { DPM) }\end{array}$ \\
\hline Feed cost (L.E ) & 792 & 639 & 590 & 470 \\
Body weight gain ( kg ) & 90 & 84 & 89 & 78 \\
Price of weight gain (L.E ) & 1620 & 1512 & 1602 & 1404 \\
Net revenue ( L.E ) & 828 & 873 & 1012 & 934 \\
Economic feed efficiency (\%) & 104.55 & 136.62 & 171.53 & 198.72 \\
Relative economic feed efficiency & 100 & 130.67 & 164.07 & 190.07 \\
\hline
\end{tabular}


Abd EL-Gawad, A.M.; Hanafy, M.A.; Shousha, MA. and Salem, O.A.I. (1989): Digestibility and blood palambeters for sheep fed rations containing poultry manure. $3^{\text {rd }}$ Egyp.-British Conf. on Animal, Fish and poultry production. pp. 431-440.

Abd El-Ghani, A.A.; Galal, A.Gh.; Meiske, J.C. and El-feel, F.M.R. (1999): Poultry litter as a feedstuff for gestating beef cows. Egypt.J.Nutr. \& Feeds, 2: 155-165.

AOAC, Association of Offcial Analytical Chemists (1990): Official Methods of Analysis. Vol. I. $14^{\text {th }}$ ed., AOAC, Arlington. Bhattacharya.

A.N. and taylor, J.C. (1975): Recycling animal waste as a feedstuff: A review. J.Anim.Sci., 41: 1438.

Caswell, L.F.; Fontenot, J.P. and Weeb, K.E. (1968): Fermentation and utilization on poultry litter ensiled at different moisture levels J.Anim.Sci., 46: 803.

Chen, K.J. and Jan, D.F. (1992): Effect of ensiled dry poultry waste in native goat ration on the rumen as evaluated by in vitro method J. Taiwan Livestock Res., 25:65.

Cross, D.L.; Skelky, G.C.; Thompson, C.S. and Jenny, B.F. (1978): Efficacy of broiler litter silage for beef steer. J.Anim.Sci., 47:544.

El-Ashry, M.A.; Khattab, H.M.; El-Serafy, A.; Soliman, H. and Abd ElMoula (1987): Nutritional value of poultry wastes for sheep. Biological wastes, 287-298.

EL-Ashry, M.A.; Saleh, H.M.; EL-Fouly, H.A. and Amin, S.O. (2000): The effect of different levels of caged layer dropping in male lamb rations on growth performance and semen characteristics. Egypt.J.Nutr. and Feeds, 3:1

Gabr, A.A.; EL-Ayek, M.Y. and Mehrez, A.Z. (1993): Effect of long term feeding of ration containing dried poultry litter on digestibility and growing lamb performance..J.Agric Sci. Mansoura Univ., 18:3437.

Gabr, A.A.; Mehrez, A.Z.; Abd EL-Khabir, A.M.; Abdel-Aziz and EL-Zalaky, O.A. (2001): Performance and some blood plasma constituents of lactating goats fed rations containing formaldehyde treated dried poultry manure. Egypt. JNutr. and Feeds, 4:46-61.

Gabr, A.A.; Abdelhamid, A.M. and EL-Ayek, M.Y. (1991): Nutritional evaluation of dried poultry litter in comparison with berseem 
hay and their mixtures as feeds for sheep. J. Agric. Sci. Mansoura Univ., 16: 2004.

Gihad, E.A.; El-Bedawy, T.M. and Mehrez, A.Z. (1980): Fibre digestibility by goat and sheep. J. Dairy Sci., 63:1701.

Hadjipanayiotou, M.; Labban, L.M.; Kronfoleh, A.; Verhaeghe, L.; Naigm, T.; Al-Wadi, M. and Amin, M. (1993): Studies on the use of dried poultry manure in ruminant rations in Syria. Livestock Anim. Res. for rural develop., 5(1): 39-45.

Harmon, B.W.; Fontenot, J.P. and Webb, K.E. (1975): Ensiled poultry litter and corn forage. I. Fermentation characteristics. J.Anim. Sci., 40(1): 144-155.

Helali, E.A.; Mohamed, A.A.; EL Khimsawy, K.A. and Borai, M.A. (1995): Use of some farm by-products in buffalo calves feeding. Proc. $5^{\text {th }}$ Sci. Conf. Animal Nutrition, 1: 129-136.

Ilian, M.A.; Razzaque, M.A. and Salmau, A.J. (1992): Unconventional feeds for sheep: Effects on performance and meat quality and composition. Biological wastes, 24(2): 115-125.

Khattab, H.M.; El-Ashry, M.A.; El-Serafy, A.M. and Soliman, H.S. (1982): Wood shaving duck litter in rations of lambs. Agric wastes, 4: 25.

Khattab, H.M.; EL-Sayed, H.M.; Elwan, K.M. and Ragheb, E.E. (1995): poultry litter incorporation in the fattening rations of male buffalo calves. Proc. $5^{\text {th }}$ Sci. Conf.Animal Nutrition, 1:145-151.

Kishan, J.; Lall, D. and Negi, S.S. (1984): Poultry litter based complete ration for sheep. Ind.J.Anim.Sci., 54:267.

Kitchennham, B.A.; Rowlands, R.; Manston, R. and Dew, S.M. (1975): The blood composition of dairy calves reared under conventional and rapid growth system. Brit.Vet. J., 31-43.

Kunkle, W.E.; Jacob, J.P.; Tervola, R.S.; Miles, R.D. and Mather, F.B. (1997): Broiler litter: Feeding to ruminants. Inst. of food and Agricultural science. Univ. of Florida.

Mabjeesh, S.J.; Arieli, A.; Bruckental, I.; Zanwell, S. and Tagari, H. (1996): Effect of type of protein supplementation on duodenal amino acid flow and absorption in lactating dairy cows. J.Dairy Sci., 79: 1792.

McCaskey, T.A.; Britt, S.N.; Ruffin, B.G.; Eason, J.T. and Strickland, R.L. (1994): Feed value of poultry litter for stocker cattle. Highlights of Alabama Agric. Res. 41(1):12.

Mehrez, A.Z. (1992): Influence of roughage: concentrate ratio on $\mathrm{N}$ requirements of rumen microbes for maximal rate of 
fermentation. Proc. of the Intern. Conf. on Manipulation of Rumen Micro-organisms to improve Efficiency of Fermentation and Ruminant Production. Alex. Egypt, pp.234. Mudgal, V.D.; Toro, V.A. and Walli, T.K. (1983): Influence of levels of poultry litter on the in vivo rumen metabolism and in vitro protein synthesis. J. Nuclear Agr. Biol., 12:76.

NRC, National Research Council (1984): Nutrient requirements of beef cattle. National Academy Press, Washington, D.C.

Okeudo, N.J. and Adegbola, A.A. (1993): Utilisation of dried caged-hen manure and cassava peels for intensive sheep production. Trop. Anim. Health prod., 25(4): 234-238.

Orskov, E.R. (1982): protein nutrition in Ruminants. Academic press Inc., London.

SAS (1995): User's Guide: Statistics, V.7.SAS Inst., Cary, NC.

Williams, D.; David, S. and Iismaa, F. (1962): Chrom-Bestimmung durch Atomabsorption-spektrophotometrie. J.Agric. Sci., 59: 381- 383.

Yildiz, G.; Fidanci, U.R.; Mugali, O.H. and Bayram, J. (1995): Influence of dried poultry manure in ration on feed evaluation and some parameters in the rumen of Akkarman lambs. Vet. Fakut. Dergisi, Ankara Univ., 42:153. 